\title{
Textural Properties and Enzyme Activity of Mango (Mangifera indica L.) Fruit Coated with Chitosan during Storage
}

\author{
Ghulam Khaliq (Corresponding author) \\ Faculty of Agriculture, Lasbela University of Agriculture, \\ Water and Marine Sciences, Uthal, Balochistan, Pakistan \\ Tel: 92-853-610923 Email: ghulam-khan@live.com \\ Mehar un Nisa \\ Department of Crop Science, Faculty of Agriculture, \\ Universiti Putra Malaysia, 43400 Serdang, Selangor, Malaysia
}

Tel: 60-389-474805 E-mail: meharnarejo@yahoo.com

Muhammad Ramzan

Faculty of Agriculture, Lasbela University of Agriculture, Water and Marine Sciences, Uthal, Balochistan, Pakistan Tel: 92-853-610923 E-mail: ramzanlund@yahoo.com

\section{Naimatullah Koondhar}

Faculty of Agriculture, Lasbela University of Agriculture,

Water and Marine Sciences, Uthal, Balochistan, Pakistan

Tel: 92-853-610923 E-mail: koondhar.naimat@gmail.com

Received: March 31, 2017

doi:10.5296/jas.v5i2.10946
Accepted: May 4, 2017 Published: May 15, 2017

URL: https://doi.org/10.5296/jas.v5i2.10946 


\section{Abstract}

Mango is a tropical fruit and deteriorates very fast after harvest due to ripening and senescence. This study investigated the effect of different concentration of chitosan coatings $0.5,1.0$ and $1.5 \%$ on postharvest quality and activities of cell wall degrading enzyme on mango cv. Choke Anan fruit stored at $25^{\circ} \mathrm{C}$ for 12 days. Fruit not treated with chitosan served as the control. The results showed that pre-storage application of chitosan coatings, especially at $1.5 \%$ significantly reduced decay symptoms, weight loss, respiration rate, ion leakage, malondialdehyde (MDA) content and maintained higher firmness of mango fruit as compared to the control. Chitosan coating treatment inhibited polygalactronase (PG) and pectin methylesterase (PME) enzyme activities. Moreover, chitosan coatings had a positive effect on retaining higher total phenolic and antioxidant activity, which reduced in the control fruit. These results suggest that chitosan coatings might be protected the fruit from quick deterioration and maintained the quality of mango by enhancing the antioxidant defense system during storage.

Keywords: Mango, Chitosan, Postharvest quality, Hydrolytic enzyme, Antioxidant capacity

\section{Introduction}

Mango is one of the most delicious fruits and has a second position worldwide after banana in the horticulture industry. Mango is a rich source of bioactive compounds such as vitamins, carotenoids, polyphenols, dietary fibers and antioxidant (Ajila et al., 2010). It has a significant antioxidant capacity, which prevents cardiovascular diseases and cancers (Yahia, 2010). Mango is a good source of a dietary triterpene called lupeo, which act as anti-microbial, anti-inflammatory and reduce cholesterol level (Siddique and Saleem, 2011). However, mango deteriorates very fast after harvest due to attack of fungal pathogens, water loss and high respiration rate, which leads to considerable postharvest losses. Moreover, various biochemical changes that take place during ripening induced degradation and senescence process of mango fruit (Liu et al., 2014).

One of the major quality concerns of mango is textural changes, which results in poor quality, and limits the shelf life during long distance transportation. Textural changes in tropical fruit are associated with the degradation of cell wall structure. Pectin is the main constituents of primary cell wall and middle lamella. Madani et al. (2014) reported that fruit softening is closely associated with the higher activities of pectin degrading enzyme such as pectin methylesterase (PME) and polygalacturanase (PG). PME hydrolyses pectin and PG degrades galacturonic acid, and thus leading to the depolymerisation and dissolution of pectin polysaccharides (Brummell and Harpster, 2001). Ripening and senescence is considered oxidative processes which induced reactive oxygen species (ROS) as a result increased lipid peroxidation, ion leakage and ultimately altered membrane structure. In a response to postharvest stress, the stimulation of antioxidant defense system can increase resistance against oxidative damage and improve quality of tropical fruits. Senescence is associated with the antioxidant defense system. An efficient antioxidant system can postpone the senescence process even though antioxidative activity in fruits decreases with ripening (Tian et al., 2013). 
Various methods such as refrigeration, modified atmosphere packaging, low temperature and heat treatments have been studied to preserve quality of mango fruit (Singh and Singh, 2012). Low temperature extends the postharvest life and control decay of fruits. However, mango is a tropical fruit and very susceptible to chilling injury, and this limit the consumer acceptability and postharvest quality. Modified atmosphere through plastic packaging is useful, but there is increasing concern about the use of non-biodegradable materials for preservation and extension the shelf life of fruits. Because, these plastic bags are not eco-friendly, create environmental problems and social concerns. Recently, consumer awareness about fresh produce is increasing and hence fruit industry continuously introduces new products which are acceptable for their clients. Synthetic fungicides have been used to inhibit decay incidence, ripening and senescence of fruits. But, fungicides cause environmental pollution, pathogen resistance and consumer concerns regarding food safety (Mari et al., 2014). Thus, there is a need to search new alternative approaches for conservation of fruit quality, which are safe, environment friendly and acceptable to industry and consumers.

Edible coatings are promising techniques to retain quality and extend the shelf-life of fruits (Jabeen et al., 2015; Majid et al., 2016). Coatings act as semipermeable membrane on the fruit skin and modify the internal atmosphere, thus inhibiting water loss, respiration rate, and oxidation reaction (Ojagh et al., 2010). Edible coatings improve the economic ability of existing packaging methods and can diminish conventional packaging materials. Currently, substantial research has been carried out on chitosan due to its film forming properties, biodegradability and antimicrobial functions (Romanazzi et al., 2017). Chitosan (1,4-linked 2-amino-2-deoxy- $\beta$-d-glucan) is a polysaccharide used for modifying the internal gas exchange and as a barrier to reduce moisture evaporation from the fruit surface. Chitosan has good physical or mechanical properties and selective permeability to carbon dioxide and oxygen gasses. Chitosan has been used as an ideal coating for maintaining quality and delaying ripening of many fruits, including longan fruits (Shi et al., 2013), strawberry (Wang and Gao, 2013; Gol et al., 2013) and table grapes (Gao et al., 2013). The effect of chitosan coating has been studied on mango fruit (Jitareerat et al., 2007; Abbasi et al., 2009; Wongmetha and Ke, 2012), however the potential of chitosan in reducing the degradation process and increasing the antioxidant defense system has not been clearly elucidated in mango fruit. So, the objectives of this work were to (1) evaluate the effect of chitosan coatings on cell wall degrading enzyme and antioxidant defense system, and (2) investigate coating effect on postharvest qualities of 'Choke Anan' mango fruit during storage at $25^{\circ} \mathrm{C}$.

\section{Materials and Methods}

\subsection{Plant Materials}

Mango (Mangifera indica L. cv. Choke Anan) fruit were harvested from a commercial orchard (Ipoh, Perak, Malaysia) at the commercial maturity stage. The fruits were transported to the laboratory within a day. Fruit were selected based on uniformity, colour, shape and size, and any infected or blemished fruit were discarded. Fruit were disinfected with sodium hypochlorite $0.01 \%(\mathrm{v} / \mathrm{v})$ for $2 \mathrm{~min}$ and then air-dried at room temperature for one hour. 
Chitosan coating solutions were prepared by dissolving $0.5,1.0$ and $1.5 \mathrm{~g}$ chitosan in $100 \mathrm{~mL}$ distilled water containing $1 \%(\mathrm{v} / \mathrm{v})$ glacial acetic acid. The solution was shaking continuously till the solution become clear. The $\mathrm{pH}$ of the solution was adjusted to 5.6 with $1 \mathrm{~mol} \mathrm{~L}^{-1}$ sodium hydroxide $(\mathrm{NaOH})$, and $0.2 \mathrm{~mL}$ of Tween-20 also added to improve wettability. These treatments were used for the experiment: (1) distilled water as a control, (2) chitosan $0.5 \%$, (3) chitosan $1.0 \%$, and (4) chitosan $1.5 \%$.

\subsection{Fruit Treatments}

Mango fruit were distributed into four samples of 60 each. The three lots were dipped in the chitosan solution for three minutes, while the control fruit dipped in distilled water. Then, the fruit were dried in air for one hour. Mango fruit were placed in plastic boxes $(40 \times 30 \times 12$ $\mathrm{cm})$ and sealed in polyethylene film $(0.02 \mathrm{~mm}$ thickness $)$ to maintain the humidity of about $70-75 \%$. The fruit were stored at $25 \pm 2{ }^{\circ} \mathrm{C}$ for 12 days. The experiment was conducted with three replications. The fruit were analyzed at (day 0 ) and at 3 day intervals, withdrawing 12 fruits per treatment at each interval.

\subsection{Evaluation of Decay Incidence}

The frequency of decay incidence was assessed according to the method of Khaliq et al. (2016a). The total decay symptoms on each fruit surface was recorded using a scale where 0 $=$ no signs of decay spot, $1=1-10 \%$ decay spot, $2=11-25 \%$ decay spot, $3=26-40 \%$ decay spot, $4=40-50 \%$ decay spot, $5=>50 \%$ decay spot.

\subsection{Weight Loss Determination}

Mango fruit were marked and weighed on day 0. Afterward, the same fruits were weighted at each sampling day during the whole storage period. Weight loss was calculated as $\%$ loss of the initial total weight.

\subsection{Fruit Firmness}

Firmness was measured using Instron Universal Testing Machine (Model 5543 P5995, USA). The penetration depth was $10 \mathrm{~mm}$ inside the fruit with a probe diameter of $6 \mathrm{~mm}$. Three readings were recorded in different places of the fruit pulp without skin. Fruit firmness was expressed in unit of Newtons $(\mathrm{N})$.

\subsection{Measurement of Respiration Rate}

One fruit was placed in $1.9 \mathrm{~L}$ airtight containers at $20^{\circ} \mathrm{C}$ for 2 hours. Respiration rate was determined by using a gas chromatograph. One milliliter of the headspace sample was injected into a gas chromatograph (Claru-500,Perkin Elmer, USA) fitted with a stainless steel Porapak Q column $(3 \mathrm{~m} \times 3.125 \mathrm{~mm}, 50 / 80 \mathrm{mesh})$. The instrument was calibrated with $1 \mathrm{~mL}$ certified standard gas. The amount of $\mathrm{CO}_{2}$ was expressed as $\mathrm{mL} \mathrm{kg}^{-1} \mathrm{~h}^{-1}$.

\subsection{Determination of Electrolyte Leakage}

Electrolyte leakage was determined following the method of Mao et al. (2007) with some modification. Cylinders were removed with a cork borer $(5 \mathrm{~mm}$ diameter) from four mango 
peel tissue. Two pieces from each cylinder of $4 \mathrm{~mm}$ thickness were cut and rinsed twice with deionized water. In a glass vial, containing $25 \mathrm{~mL}$ deionised water and 12 pieces of cylinder were shaken at $1.7 \mathrm{~s}^{-1}$ for $30 \mathrm{~min}$ at $25^{\circ} \mathrm{C}$ using a shaker, SK 300, Jeio Tech, Korea. Then, the glass vial was heated in boiling water for $15 \mathrm{~min}$ at $98^{\circ} \mathrm{C}$. Electrolyte leakage was determined before heating and after cooling with conductivity meter and expressed on percentage basis.

\subsection{Measurement of Malondialdehyde (MDA) Content}

The MDA content in mango peel was measured following the method of Yang et al. (2011). One gram of peel tissue was homogenized in $5.0 \mathrm{~mL}$ of $10 \%$ trichloroacetic acid (TCA) using a pestle and mortar and the homogenate was then centrifuged at $12,000 \times g$ for 20 min at $4{ }^{\circ} \mathrm{C}$ (Scan Speed 1730R, Scala Scientific, Netherlands). The supernatant $2 \mathrm{~mL}$ was added to $2 \mathrm{~mL}$ of $0.67 \%$ thiobarbituric acid, heated for $20 \mathrm{~min}$ at $100^{\circ} \mathrm{C}$ in boiling water and then directly cooled on ice. The mixture was centrifuged at $3000 \times g$ for $10 \mathrm{~min}$ (ALC, PK110, Italy). The absorbance was measured at $532 \mathrm{~nm}$, and subtracted from nonspecific absorbance at 600 and $450 \mathrm{~nm}$ using a spectrophotometer (Multiskan Go, Thermo Fisher Scientific, Finland). MDA content was expressed as $\mu \mathrm{mol} \mathrm{kg}{ }^{-1}$ on a fresh weight basis. MDA content was calculated using the formula. MDA content $\left(\mu \mathrm{mol} \mathrm{kg}{ }^{-1}\right)=\left[6.45 \times\left(\mathrm{OD}_{532}-\mathrm{OD}_{600}\right)-0.56 \times \mathrm{OD}_{450}\right]$.

\subsection{Assay of Polygalacturonase (PG) and Pectin Methylesterase (PME) Activities}

To obtain the enzyme extract, mango peel tissue $1 \mathrm{~g}$ was homogenised with $5 \mathrm{~mL}$ of sodium phosphate buffer $\left(50 \mathrm{mmol} \mathrm{L}^{-1}, \mathrm{pH} 7.0\right)$ containing $1 \%(\mathrm{w} / \mathrm{v})$ polyvinylpolypyrrolidone (PVPP) and $1 \mathrm{mmol} \mathrm{L}^{-1}$ ethylene diamine tetraacetic acid (EDTA) using pre-chilled pestle and mortar. The homogenate was then centrifuged at $15,000 \times g$ for $30 \mathrm{~min}$ at $4{ }^{\circ} \mathrm{C}$ (Scan Speed 1730R, Scala Scientific, Netherlands). The supernatant was used for PG and PME enzyme assay.

PG activity was measured following the method of Zhou et al. (2000). The reaction mixture consisted of $1 \mathrm{~mL}$ of $0.5 \%$ polygalacturonic acid, $1 \mathrm{~mL}$ sodium phosphate buffer $(50 \mathrm{mmol}$ $\mathrm{L}^{-1}, \mathrm{pH} 7.0$ ) and $1 \mathrm{~mL}$ of $\mathrm{PG}$ extract. The reaction mixture was incubated at $37^{\circ} \mathrm{C}$ for $6 \mathrm{~h}$ and then measured by 3,5-dinitrosalicylic acid reagent at $540 \mathrm{~nm}$. One unit of specific enzyme activity was defined as $1 \mu \mathrm{g}$ galacturonic acid released per mg protein per hour. Protein content was measured following the method of Bradford (1976) using bovine serum albumin as the standard.

PME activity was also measured following the method of Zhou et al. (2000). Twenty millilitre of $1 \%$ citrus pectin was mixed with $5 \mathrm{~mL} \mathrm{PME}$ extract and titrated with $1 \mathrm{mmol} \mathrm{L}^{-1}$ $\mathrm{NaOH}$ to maintain $\mathrm{pH} 7.4$, while incubated at $30^{\circ} \mathrm{C}$. The reaction was measured for $30 \mathrm{~min}$. One unit of enzyme activity was defined as $1 \mathrm{mmol} \mathrm{NaOH}$ consumed per mg protein per hour.

\subsection{Total Phenolic Content}

Total phenolic content were measured following the procedure of Zieslin and Ben-Zaken (1993) and expressed as mass of gallic acid equivalents (GAE) $\mathrm{g} \mathrm{kg}^{-1}$ on a fresh weight basis. 


\subsection{Antioxidant Capacity}

DPPH (2, 2-diphenyl-1-picryl hydrazyl) radical scavenging activity was evaluated following the method of Brand-Williams et al. (1995). Mango peel tissue $1 \mathrm{~g}$ was homogenized in $8 \mathrm{~mL}$ absolute methanol and then centrifuged at $10,000 \times g$ for $20 \mathrm{~min}$ at $4{ }^{\circ} \mathrm{C}$. The supernatant was used in the DPPH assay. An aliquot $(0.1 \mathrm{~mL})$ of the methanol extract was added to $3.9 \mathrm{~mL}$ of $0.063 \mathrm{mmol} \mathrm{L}^{-1}$ DPPH-methanol solution. The reaction mixture was incubated at room temperature for $20 \mathrm{~min}$, and the absorbance was observed at $515 \mathrm{~nm}$ against a blank.

\subsection{Statistical Analysis}

The experiment was conducted in a completely randomized design (CRD) with two factors (storage days and dipping treatments). There were three replications for each treatment. The data were subjected to analysis of variance (ANOVA) using SAS, version 9.3 (SAS Institute Inc., Cary, NC, USA). The means were compared using least significant differences (LSD) at significance level of $P \leq 0.05$.

\section{Results}

\subsection{Decay Incidence}

Mango is a highly susceptible to pathogenic infection and its resistance gradually decreases during ripening. In general, the results showed that decay incidence of mango fruit increased in all samples as the time progressed (Table 1). However, from day 3 up to the end of storage, mango fruit coated with chitosan 1.0 and $1.5 \%$, significantly $(P \leq 0.05)$ inhibited decay symptoms as compared to the control. The result showed no significant $(P \geq 0.05)$ differences between the control and fruit treated with chitosan $0.5 \%$ during the entire storage period excluding on day 6 . The decay incidence was 88 and $91 \%$ lower in fruit coated with chitosan 1.0 and $1.5 \%$ respectively, compared to uncoated fruit at the end of storage.

\subsection{Weight Loss}

Moisture evaporation from the fruit to the environment and oxidation of organic acids during respiration are the main causes of weight loss. This leads to a decrease the commercial value of the fruit. As shown in (Table 1), the fruit coated with chitosan $0.5 \%$ and control exhibited a higher weight loss at the end of the experiment. From day 3 up to the end of the storage period, mango fruit treated with chitosan 1.0 and $1.5 \%$, significantly $(P \leq 0.05)$ reduced weight loss than the control. The lowest weight loss was found in fruit coated with chitosan $1.5 \%$ at the end of the experiment.

\subsection{Firmness}

Fruit texture is one of the most important parameters of quality determination. Fruit textural changes are generally associated with the hydrolysis of starch to sugar and the degradation of pectin in cell wall during ripening. Fruit firmness gradually decreased in both treated and untreated fruit during the whole storage period (Table 1). In this study, fruit coated with chitosan 1.0 and $1.5 \%$ maintained their textural integrity than the control and fruit treated with chitosan $0.5 \%$. No significant $(P \geq 0.05)$ differences were observed between the control 
Table 1. Effect of chitosan coatings on decay incidence, weight loss and firmness of mango fruit during storage at $25^{\circ} \mathrm{C}$ for 12 days.

\section{Storage time (days)}

\begin{tabular}{lccccc}
\cline { 2 - 6 } Treatments & \multicolumn{1}{c}{$\mathbf{0}$} & $\mathbf{3}$ & $\mathbf{6}$ & $\mathbf{9}$ & $\mathbf{1 2}$ \\
& \multicolumn{5}{c}{ Decay incidence (\%) } \\
& & & & \\
Control & $0.0 \pm 0.0 \mathrm{a}$ & $5.33 \pm 1.85 \mathrm{a}$ & $20.89 \pm 3.75 \mathrm{a}$ & $30.35 \pm 3.68 \mathrm{a}$ & $46.66 \pm 4.91 \mathrm{a}$ \\
Chitosan $0.5 \%$ & $0.0 \pm 0.0 \mathrm{a}$ & $2.0 \pm 1.52 \mathrm{ab}$ & $9.45 \pm 2.53 \mathrm{~b}$ & $26.14 \pm 4.44 \mathrm{a}$ & $34.55 \pm 4.84 \mathrm{a}$ \\
Chitosan $1.0 \%$ & $0.0 \pm 0.0 \mathrm{a}$ & $0.0 \pm 0.0 \mathrm{~b}$ & $2.20 \pm 1.56 \mathrm{~b}$ & $3.66 \pm 2.06 \mathrm{~b}$ & $5.33 \pm 2.60 \mathrm{~b}$ \\
Chitosan $1.5 \%$ & $0.0 \pm 0.0 \mathrm{a}$ & $0.0 \pm 0.0 \mathrm{~b}$ & $1.04 \pm 1.03 \mathrm{~b}$ & $2.07 \pm 1.47 \mathrm{~b}$ & $3.93 \pm 2.55 \mathrm{~b}$
\end{tabular}

Weight loss (\%)

$\begin{array}{llllll}\text { Control } & 0.0 \pm 0.0 \mathrm{a} & 2.85 \pm 0.37 \mathrm{a} & 5.53 \pm 0.65 \mathrm{a} & 12.56 \pm 1.09 \mathrm{a} & 15.31 \pm 1.55 \mathrm{a} \\ \text { Chitosan } 0.5 \% & 0.0 \pm 0.0 \mathrm{a} & 1.60 \pm 0.24 \mathrm{ab} & 4.22 \pm 0.65 \mathrm{ab} & 9.08 \pm 0.63 \mathrm{~b} & 12.36 \pm 1.70 \mathrm{a} \\ \text { Chitosan 1.0\% } & 0.0 \pm 0.0 \mathrm{a} & 1.06 \pm 0.46 \mathrm{~b} & 3.04 \pm 0.32 \mathrm{bb} & 5.04 \pm 0.87 \mathrm{c} & 6.84 \pm 1.34 \mathrm{~b} \\ \text { Chitosan 1.5\% } & 0.0 \pm 0.0 \mathrm{a} & 0.80 \pm 0.50 \mathrm{~b} & 2.22 \pm 0.86 \mathrm{~b} & 4.54 \pm 0.84 \mathrm{c} & 6.22 \pm 1.02 \mathrm{~b}\end{array}$

Firmness (N)

\begin{tabular}{llllll} 
Control & $98.53 \pm 1.44 \mathrm{a}$ & $70.66 \pm 4.45 \mathrm{~b}$ & $50.00 \pm 4.18 \mathrm{c}$ & $35.66 \pm 4.37 \mathrm{c}$ & $20.00 \pm 2.49 \mathrm{~b}$ \\
Chitosan 0.5\% & $99.00 \pm 1.24 \mathrm{a}$ & $77.33 \pm 4.95 \mathrm{~b}$ & $66.00 \pm 2.86 \mathrm{~b}$ & $45.33 \pm 4.72 \mathrm{bc}$ & $25.21 \pm 3.06 \mathrm{~b}$ \\
Chitosan 1.0\% & $97.66 \pm 1.65 \mathrm{a}$ & $92.66 \pm 2.68 \mathrm{a}$ & $80.66 \pm 3.13 \mathrm{ab}$ & $65.42 \pm 3.78 \mathrm{ab}$ & $55.72 \pm 4.95 \mathrm{a}$ \\
Chitosan 1.5\% & $97.37 \pm 1.71 \mathrm{a}$ & $95.66 \pm 1.96 \mathrm{a}$ & $85.33 \pm 4.04 \mathrm{a}$ & $80.00 \pm 4.08 \mathrm{a}$ & $66.32 \pm 4.80 \mathrm{a}$ \\
\hline
\end{tabular}

Means with the same letters within a column are not significantly different at $(P \leq 0.05)$ using LSD. Each value represents a mean \pm standard error $(n=3)$.

and fruit coated with chitosan $0.5 \%$ throughout the storage period except on day 6 . At the end of experiment, chitosan 1.0 and $1.5 \%$ coated fruits maintained 63 and $69 \%$ higher firmness respectively, than the uncoated fruit.

\subsection{Respiration Rate}

In climacteric fruits, respiration is one of the most significant quality parameter and has been the subject of more discussion. Generally, chitosan treatment inhibited the respiration rate of mango fruit during storage (Table 2). The climacteric peak height was recorded in the uncoated and chitosan $0.5 \%$ treated fruits at day 6 , and after that it decreased suddenly up to the end of storage. Conversely, fruit coated with chitosan 1.0 and $1.5 \%$ delayed the respiration peak and was observed at day 9 . The peak value in chitosan 1.0 and $1.5 \%$ coated fruit was 8 and $24 \%$ lower than the control, respectively. 


\subsection{Electrolyte Leakage}

Electrolyte leakage is a qualitative indicator of membrane permeability and determines the physical damage of membrane structure. Generally, the ion leakage of mango fruit gradually increased with the increase in storage period, regardless of the chitosan treatments as shown in Table 2. However, in control fruit, ion leakage increased more rapidly than the coated fruit. From day 6 up to the end of the experiment, chitosan 1.0 and $1.5 \%$ coated fruit significantly $(P \leq 0.05)$ reduced ion leakage than the uncoated fruit. Whereas, no statistical differences can be seen between chitosan $0.5 \%$ coated fruit and control during the whole storage period except on day 6.

Table 2. Effect of chitosan coatings on respiration rate, electrolyte leakage and MDA content of mango fruit during storage at $25^{\circ} \mathrm{C}$ for 12 days.

\begin{tabular}{|c|c|c|c|c|c|}
\hline \multirow[b]{2}{*}{ Treatments } & \multicolumn{4}{|c|}{ Storage time (days) } & \multirow[b]{2}{*}{12} \\
\hline & $\mathbf{0}$ & 3 & 6 & 9 & \\
\hline \multicolumn{6}{|c|}{$\mathrm{CO}_{2}\left(\mathrm{~mL} \mathrm{~kg}^{-1} \mathrm{~h}^{-1}\right)$} \\
\hline Control & $17.7 \pm 3.18 \mathrm{a}$ & $34.6 \pm 3.52 \mathrm{a}$ & $57.0 \pm 4.58 \mathrm{a}$ & $35.9 \pm 3.16 b$ & $24.9 \pm 3.50 b$ \\
\hline Chitosan $0.5 \%$ & $16.6 \pm 2.10 \mathrm{a}$ & $28.5 \pm 3.17 \mathrm{ab}$ & $50.3 \pm 2.90 \mathrm{a}$ & $40.6 \pm 2.02 \mathrm{ab}$ & $34.0 \pm 2.97 \mathrm{ab}$ \\
\hline Chitosan $1.0 \%$ & $16.6 \pm 2.98 \mathrm{a}$ & $23.3 \pm 3.3 \mathrm{ab}$ & $26.7 \pm 2.96 b$ & $52.0 \pm 4.16 \mathrm{a}$ & $45.2 \pm 3.27 \mathrm{a}$ \\
\hline Chitosan $1.5 \%$ & $17.4 \pm 3.28 \mathrm{a}$ & $21.4 \pm 3.2 b$ & $30.6 \pm 3.75 b$ & $43.3 \pm 3.38 \mathrm{ab}$ & $40.5 \pm 3.77 \mathrm{a}$ \\
\hline \multicolumn{6}{|c|}{ Electrolyte leakage (\%) } \\
\hline Control & $12.6 \pm 1.27 \mathrm{a}$ & $24.1 \pm 2.24 \mathrm{a}$ & $37.1 \pm 2.46 \mathrm{a}$ & $50.1 \pm 3.60 \mathrm{a}$ & $55.9 \pm 2.63 \mathrm{a}$ \\
\hline Chitosan $0.5 \%$ & $12.6 \pm 1.77 \mathrm{a}$ & $22.1 \pm 2.31 \mathrm{ab}$ & $28.3 \pm 3.52 b$ & $44.3 \pm 3.71 \mathrm{a}$ & $47.3 \pm 3.28 \mathrm{ab}$ \\
\hline Chitosan $1.0 \%$ & $13.6 \pm 1.34 \mathrm{a}$ & $17.4 \pm 2.82 \mathrm{ab}$ & $20.0 \pm 2.51 b c$ & $31.5 \pm 2.82 b$ & $35.6 \pm 2.40 b c$ \\
\hline Chitosan $1.5 \%$ & $12.9 \pm 1.42 \mathrm{a}$ & $13.3 \pm 2.11 b$ & $18.2 \pm 2.66 \mathrm{c}$ & $23.2 \pm 2.55 b$ & $28.4 \pm 3.64 c$ \\
\hline \multicolumn{6}{|c|}{ MDA content $\left(\mu \mathrm{mol} \mathrm{kg}{ }^{-1}\right)$} \\
\hline Control & $0.30 \pm 0.06 \mathrm{a}$ & $0.58 \pm 0.07 \mathrm{a}$ & $0.72 \pm 0.06 \mathrm{a}$ & $0.97 \pm 0.06 \mathrm{a}$ & $1.05 \pm 0.05 \mathrm{a}$ \\
\hline Chitosan $0.5 \%$ & $0.31 \pm 0.03 a$ & $0.53 \pm 0.05 \mathrm{ab}$ & $0.70 \pm 0.05 a$ & $0.85 \pm 0.05 a$ & $0.94 \pm 0.07 \mathrm{a}$ \\
\hline Chitosan $1.0 \%$ & $0.33 \pm 0.05 a$ & $0.40 \pm 0.03 b$ & $0.48 \pm 0.06 b$ & $0.62 \pm 0.06 b$ & $0.74 \pm 0.06 b$ \\
\hline Chitosan $1.5 \%$ & $0.32 \pm 0.07 \mathrm{a}$ & $0.38 \pm 0.04 b$ & $0.46 \pm 0.05 b$ & $0.54 \pm 0.07 b$ & $0.55 \pm 0.05 c$ \\
\hline
\end{tabular}

Means with the same letters within a column are not significantly different at $(P \leq 0.05)$ using LSD. Each value represents a mean \pm standard error $(n=3)$.

\subsection{MDA Content}

Malondialdehyde is a stress marker and used as a reliable index during deterioration process. It reflects oxidative damage and increased production of MDA associated with the fruit 
ripening process. The result showed that MDA content progressively increased irrespective of dipping treatments with increasing the storage periods as indicated in Table 2. Mango fruit treated with chitosan 1.0 and $1.5 \%$, significantly $(P \leq 0.05)$ reduced MDA content compared to the untreated fruit at the end of storage period by 29 and $47 \%$, respectively. Conversely, the differences were not significant $(P \geq 0.05)$ between the control and fruit treated with chitosan $0.5 \%$ during the whole storage period.

\subsection{PG and PME Enzyme Activities}

PG and PME are considered cell wall degrading enzyme and mostly associated with fruit ripening and textural changes. The PG enzyme activity in mango fruit increased with progressing the storage period, but the increase was more evident in the uncoated fruit (Figure 1A). From day 3 up to the end of storage, mango fruit coated with chitosan 1.0 and $1.5 \%$ had significantly $(P \leq 0.05)$ reduced $\mathrm{PG}$ activity compared to the control. The highest activity of PG was observed in uncoated fruit, while, the lowest in chitosan $1.5 \%$ treated fruit at the end of storage. PME activity also increased in all samples up to day 9, and after that it decreased rapidly (Figure 1B). At the end of storage, PME activity was lower in fruit subjected to chitosan 1.0 and $1.5 \%$ by 49 and $55 \%$ respectively, than those of the control fruit. 

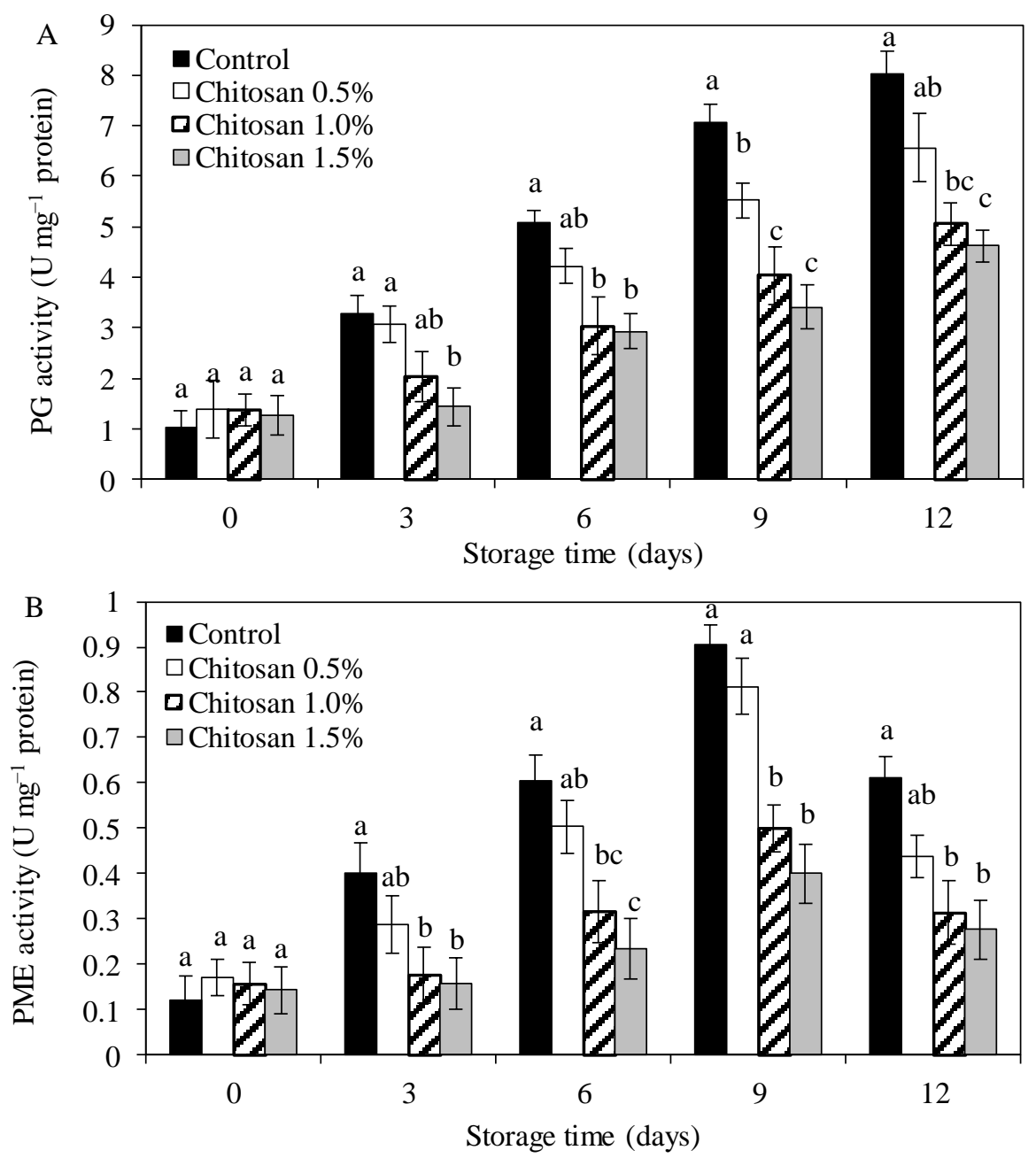

Figure 1. PG (A) and PME (B) enzyme activities in mango fruit as influenced by chitosan coating during storage at $25^{\circ} \mathrm{C}$ for 12 days. Means with the same letters for each day are not significantly different at $(\mathrm{P} \leq 0.05)$ using LSD. Each data point represents a mean \pm standard error $(n=3)$

\subsection{Total Phenolic Content}

Phenolic compounds have antioxidant properties and induced under stress conditions. The result shows that the phenolic content declined in all mango samples irrespective of coating treatments throughout the storage duration (Figure 2A). However, this decline trend was more noticeable in the control and chitosan $0.5 \%$ treated fruit. From day 6 till the end of storage, mango fruit coated with chitosan $1.5 \%$, significantly $(\mathrm{P} \leq 0.05)$ preserved total phenolic content than the control fruit. There were no significant $(\mathrm{P} \geq 0.05)$ differences can be seen between chitosan $0.5 \%$ coated fruit and control during the whole storage period. 


\section{Macrothink}
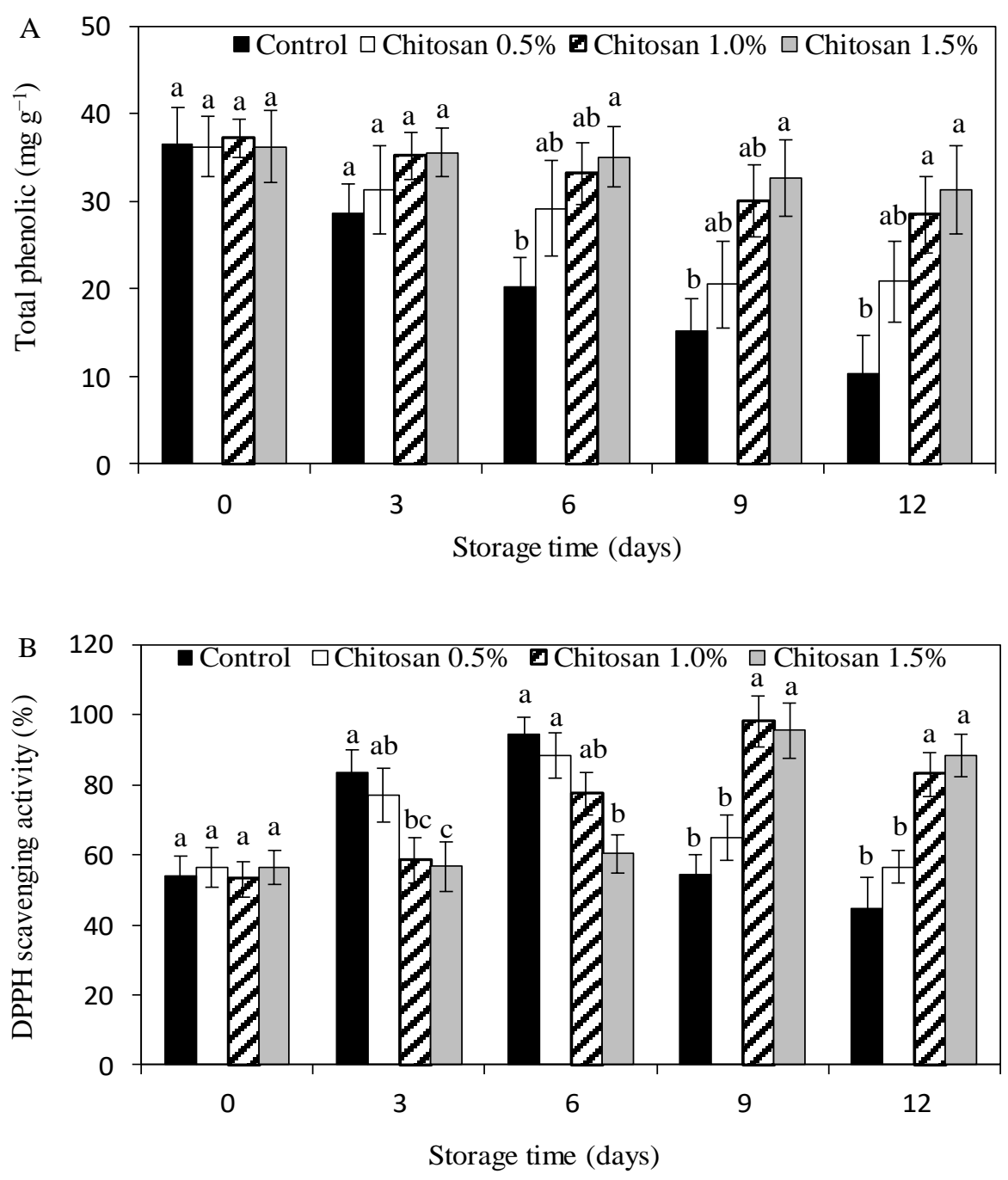

Figure 2. Total phenolic (A) and DPPH activity (B) in mango fruit as influenced by chitosan coating during storage at $25^{\circ} \mathrm{C}$ for 12 days. Means with the same letters for each day are not significantly different at $(P \leq 0.05)$ using LSD. Each data point represents a mean \pm standard error $(n=3)$.

\subsection{Antioxidant Capacity}

The DPPH-radical scavenging activity is an appropriate parameter for determining the possible health benefits of fresh fruits. The DPPH activity of coated and uncoated mango is indicated in Figure 2B. The changes in DPPH-radical scavenging activities were same for chitosan $0.5 \%$ treated mango and the control during storage. They all showed an increase during the first 6 days, and afterward they suddenly decreased up to the end of storage. The changing trend in chitosan 1.0 and $1.5 \%$ coated fruit was similar during the whole storage period. Chitosan 1.0 and $1.5 \%$ coated fruit significantly $(P \leq 0.05)$ maintained higher levels of DPPH-radical scavenging activity than the chitosan $0.5 \%$ coated and uncoated fruit at the end of storage. 


\section{Discussion}

Mango is a highly perishable fruit and ripening process further accelerates the biochemical changes which affect the fruit composition and quality. These results showed that chitosan coatings can reduce the decay symptoms of mango fruit during storage at $25^{\circ} \mathrm{C}$. Two mechanisms have been described in the previous findings about chitosan to reduce pathogen growth. One theory is that chitosan release some products which could be interact with the fungal DNA, and as a result disturbing protein synthesis and mRNA (Zakrzewska et al., 2005). Another argument is that in fungal cell, chitosan interact with the negatively charged molecules and this causes the loss of ion leakage and protein constituents (Meng et al., 2008). Chitosan coatings inhibit the growth and induce morphological changes in hyphae structure. Bautista-Baños et al. (2006) reported that chitosan coatings prevented spore germination and mycelial growth of several fungi, and thus chitosan show antifungal properties. It has been known that chitosan coatings increased resistance in the host plant tissues against pathogens in fruits (Romanazzi et al., 2017). Previous studies indicated that chitosan coatings inhibited decay symptoms and ripening in various fruits, including peach (Ma et al., 2013), strawberry (Gol et al., 2013) and table grapes (Gao et al., 2013). Mango fruit coated with chitosan 1.0 and $1.5 \%$ efficiently delayed the ripening and reduced the decay incidence throughout the storage time. The potential of chitosan to postpone the ripening process in mango fruit might be attributed to induce its resistance against pathogen infection.

Water loss from the fruit surface causes shrivelling which limits the postharvest quality of fruit. It has been observed that weight loss is related with evaporation of water from the fruit surface and respiration rate (Jitareerat et al., 2007). In this study, chitosan coating reduced weight loss of mango probably by forming a protective barrier on the fruit surface, thereby inhibited water evaporation and gas exchange. Similar performance by reducing weight loss has been observed in chitosan treated strawberry, litchi and dragon fruit (Gol et al., 2013; Lin et al., 2011; Ali et al., 2013). Consumers purchase fruits on the basis of appearance and textural quality (Nayik and Muzaffar, 2014; Nayik et al., 2015). Fruit textural changes are associated with water loss, which decrease the turgor pressure and crispness of fresh fruit (Yang et al., 2014). Moreover, fruit softening is also related to the changes in cell wall composition. During ripening, the activities of hydrolytic enzymes increased and this caused loss of firmness (Razzaq et al., 2014). Mango firmness is highly decreased in the control fruit than coated fruits. The loss of firmness in the control fruit might be attributed to the increase activities of hydrolytic enzyme and water loss. These results are confirmed by previous reports, whereas chitosan coating maintained high firmness in sweet pepper, pear and peach (Xing et al., 2011; Zhou et al., 2011; Ma et al., 2013). It has been known that respiration rate of climacteric fruits increased during the storage period at ambient temperature. However, many studies showed that edible coatings reduced respiration rate in fruits (Lima et al., 2010; Lin et al., 2011; Gao et al., 2013). Chitosan coating effectively inhibited respiration rate and delayed ripening of mango fruit. In this study, the effect of chitosan coatings on respiration rate can be explained by the fact that chitosan coating acts as a fence on the fruit skin and modified the internal atmosphere with reduction of $\mathrm{O}_{2}$ concentration and enhanced $\mathrm{CO}_{2}$.

Cell wall and cell membrane are considered the first lines of defense against various stresses. 
During the ripening process, maintenance of cell membrane integrity is essential for cell survival and possible health of plant tissues. Alterations in membrane physical structure are closely associated with fruit senescence, which causes ion leakage and leads to a loss of membrane permeability and function (Saltveit, 2002). Additionally, rapid changes during senescence disrupt membrane composition and decreased fluidity of membrane as a result increased ion leakage (Marangoni et al., 1996). Edible coating reduced ion leakage and maintained a high integrity of cell membranes of mango fruit during storage (Khaliq et al., 2016b). A possible explanation for the decreased ion leakage in treated mango might be due to reduction in lipid peroxidation and higher level of unsaturated/saturated fatty acid ratio, thereby preserved the cell membrane integrity. MDA content provides a reflection of oxidative deterioration during ripening and senescence of fruit. Lipid peroxidation induced the saturation of fatty acids, reduction of galactolipids, phospholipids and an increase in the sterol/phospholipid ratio that finally affected the membrane fluidity and functions (Marangoni et al., 1996). In the present findings, treatments with chitosan 1.0 and $1.5 \%$ significantly reduced MDA content than the control fruit (Table 1). These findings further support the idea of Xing et al. (2011) who reported that chitosan coating reduced electrolyte leakage, MDA content, decay incidence and retained a high integrity of cell membranes in sweet pepper during cold storage. The inhibition of the ripening process in treated mango fruit might be due to reduction of MDA content and ion leakage in the coated fruit.

Pectin substances are the main component of cell wall structure and play an essential role in maintaining fruit firmness. Degradation of pectin, cellulose and hemicellulose result in disintegration of cell wall structure. The cell wall polymers breakdown is closely associated with the activity of pectolytic enzyme during ripening and senescence. PG and PME enzyme are responsible for the disintegration of a cell wall component, especially pectin and other polysaccharides (Zhang et al., 1997). During ripening, pectolytic enzymes induce which lead to the decomposition of the non-soluble pectic compounds, and this result in tissue degeneration and cell separation. PME disintegrates the methyl and the carboxylic groups of the pectin and breaks the ester bonds, while PG acts on pectic acid chains and break the glycoside bonds between the galacturonic acid subunits (Brummell and Harpster, 2001). It has been observed that the cell wall degrading enzyme increased during ripening in mango (Razzaq et al., 2014), papaya (Madani et al., 2014) and Jamun (Baraiya et al., 2015). However, mango fruit treated with chitosan reduced the activities of PG and PME enzyme in this study. These results are in line with previous reports, where edible coatings decreased the activities of pectolytic enzyme in pear and jamun during storage (Zhou et al., 2011; Baraiya et al., 2015). Chitosan coating positively inhibited the activities of PG and PME enzyme. The early senescence and loss of firmness in the control fruit could be attributed to the higher activities of PG and PME enzyme. While, higher firmness of coated fruit might be due to reduce activity of PG and PME enzyme.

Several biotic and abiotic factors are responsible for excessive production of reactive oxygen species (ROS) in fruits. Pathogen (fungi, bacteria and viruses) which attack plant tissue and caused various diseases induced excess production of ROS (Low and Merida, 1996). Postharvest factors such as injuries, storage atmosphere and water loss also accelerate 
oxidative stress in fruits (Toivonen, 2003). Similarly, ripening and senescence of fruits is related to the over production of ROS (Hodges et al., 2004). Excess production of ROS damaged lipids, protein, carbohydrate, DNA and decreased antioxidant capacity (Karuppanapandian et al., 2011). For the detoxification of ROS, plant cells contain antioxidant defense mechanisms, which remove the over production of ROS under stress conditions (Karuppanapandian et al., 2011). Phenolic compounds have antioxidant properties and ideal structural chemistry for quenching ROS in plant cells (Jung et al., 2003). Polyphenols are highly reactive to chelate transition metal ions and as hydrogen or electron donors. It is essential to maintain balance between oxidative damage and antioxidant for a healthy biologic system. Palafox-Carlos et al. (2012) stated a link between total phenolic content and antioxidant activity in mango fruit. The higher phenolic content in mango treated with chitosan can be contributed to improve antioxidant activity. Several studies showed that chitosan coatings enhanced total phenolic and antioxidant activity in fruits, including dragon fruit (Ali et al., 2013), strawberry (Wang and Gao, 2013) and blueberry (Yang et al., 2014). These results can be explained by the facts that chitosan coatings could be reduced oxidative damage by enhancing the antioxidant defense system, and thus maintained mango fruit quality.

\section{Conclusion}

Chitosan is nontoxic and have the potential as pre-storage agents to maintain the postharvest quality of 'Choke Anan' mango fruit during storage, which otherwise would lead to deterioration. Chitosan coating was efficiently inhibited textural changes by reducing cell wall degrading enzyme activities. The ripening process was delayed, and ion leakage and MDA content reduced in chitosan treated fruit. These treatments enhanced the antioxidant activity and phenolic content, thereby increased resistance against oxidative damage. This study suggested that application of chitosan coatings dipping treatment could be a promising techniques for reducing physicochemical changes and maintaining postharvest quality of mango fruit during storage.

\section{Acknowledgement}

This study was supported by the Lasbela University of Agriculture Water and Marine Sciences, Uthal, Balochistan, Pakistan and Ghulam Khaliq gratefully acknowledges the LUAWMS for financial support.

\section{References}

Abbasi, N. A., Iqbal, Z., Maqbool, M., \& Hafiz, I. A. (2009). Postharvest quality of mango (Mangifera indica L.) fruit as affected by chitosan coating. Pakistan Journal of Botany, 41(1), 343-357.

Ajila, C. M., Aalami, M., Leelavathi, K., \& Rao, U. J. S. P. (2010). Mango peel powder: A potential source of antioxidant and dietary fiber in macaroni preparations. Innovative Food Science and Emerging Technologies, 11, 219-224.

http://dx.doi.org/10.1016/j.ifset.2009.10.004 
Ali, A., Zahid, N., Manickam, S., Siddiqui, Y., Aldersond, P. G., \& Maqbool, M. (2013). Effectiveness of submicron chitosan dispersions in controlling anthracnose and maintaining quality of dragon fruit. Postharvest Biology and Technology, 86, 147-153. http://dx.doi.org/10.1016/j.postharvbio.2013.06.027

Baraiya, N. S., Rao, T. V. R., \& Thakkar, V. R. (2015). Improvement of postharvest quality and storability of jamun fruit (Syzygium cumini L. var. Paras) by zein coating enriched with antioxidants. Food and Bioprocess Technology, 8, 2225-2234.

http://doi: 10.1007/s11947-015-1577-x

Bautista-Baños, S., Hernández-Lauzardo, A. N., Velázquezdel Valle, M. G., Hernández-López, M., Ait Barka, E., Bosquez-Molina, E., \& Wilson, C. L. (2006). Chitosan as a potential natural compound to control pre and postharvest diseases of horticultural commodities. Crop Protection, 25, 108-118.

Bradford, M. M. (1976). A rapid and sensitive method for the quantitation of microgram quantities of protein utilising the principle of protein-dye binding. Analytical Biochemistry, 72, 248-254.

Brand-Williams, W., Cuvelier, M. E., \& Berset, C. (1995). Use of free radical method to evaluate antioxidant activity. LWT-Food Science and Technology, 28, 25-30.

http://dx.doi.org/10.1016/S0023-6438(95)80008-5

Brummell, D. A., \& Harpster, M. H. (2001). Cell wall metabolism in fruit softening and quality and its manipulation in transgenic plants. Plant Molecular Biology, 47, 311-340. http://doi: 10.1023/A:1010656104304

Chien, P., Sheu, F., \& Yang, F. (2007). Effects of edible chitosan coating on quality and shelf life of sliced mango fruit. Journal of Food Engineering, 78(1), 225-229. http://dx.doi.org/10.1016/j.jfoodeng.2005.09.022

Gao, P., Zhu, Z., \& Zhang, P. (2013). Effects of chitosan-glucose complex coating on postharvest quality and shelf life of table grapes. Carbohydrate Polymers, 95, 371- 378. http://dx.doi.org/10.1016/j.carbpol.2013.03.029

Gol, N. B., Patel, P. R., \& Rao, T. V. R. (2013). Improvement of quality and shelf-life of strawberries with edible coatings enriched with chitosan. Postharvest Biology and Technology, 85, 185-195. http://dx.doi.org/10.1016/j.postharvbio.2013.06.008

Hodges, D. M., Lester, G. E., Munro, K. D., \& Toivonen, P. M. A. (2004). Oxidative stress: Importance for postharvest quality. HortScience, 39, 924-929.

Jabeen, N., Majid, I., \& Nayik, G.A. (2015). Bioplastics and food packaging: A review. Cogent Food \& Agriculture, 1(1), 1-6. http://dx.doi.org/10.1080/23311932.2015.1117749

Jitareerat, P., Paumchai, S., Kanlayanarat, S., \& Sangchote, S. (2007). Effect of chitosan on ripening, enzymatic activity, and disease development in mango (Mangifera indica) fruit. New Zealand Journal of Crop and Horticultural Science, 35, 211-218.

http://dx.doi.org/10.1080/01140670709510187 
Jung, M., Kim, H., Lee, K., \& Park, M. (2003). Naturally occurring peroxides with biological activities. Mini-Reviews in Medicinal Chemistry, 3, 159-65.

Karuppanapandian, T., Moon, J. C., Kim, C., Manoharan, K., \& Kim, W. (2011). Reactive oxygen species in plants: their generation, signal transduction, and scavenging mechanisms. Australian Journal of Crop Science, 5, 709-725.

Khaliq, G., Mahmud, T. M. M., Ding, P., Ghazali, H. M., \& Ali, A. (2016a). Storage behaviour and quality responses of mango (Mangifera indica L.) fruit treated with chitosan and gum arabic coatings during cold storage conditions. International Food Research Journal, 23, 141-148.

Khaliq, G., Mahmud, T. M. M., Ghazali, H. M., Ding, P., \& Ali, A. (2016b). Influence of gum arabic coating enriched with calcium chloride on physiological, biochemical and quality responses of mango (Mangifera indica L.) fruit stored under low temperature stress. Postharvest Biology and Technology, 111, 362-369.

http://dx.doi.org/10.1016/j.postharvbio.2015.09.029

Lima, A. M., Cerqueira, M. A., Souza, B. W. S., Santos, E. C. M., Teixeira, J. A., Moreira, R. A., \& Vicente, A. A. (2010). New edible coatings composed of galactomannans and collagen blends to improve the postharvest quality of fruits - Influence on fruits gas transfer rate. Journal of Food Engineering, 97, 101-109. http://dx.doi.org/10.1016/j.jfoodeng.2009.09.021

Lin, B., Du, Y., Liang, X., Wang, X., Wang, X., \& Yang, J. (2011). Effect of chitosan coating on respiratory behavior and quality of stored litchi under ambient temperature. Journal of Food Engineering, 102(1), 94-99. http://dx.doi.org/10.1016/j.jfoodeng.2010.08.009

Liu, K., Wang, X., \& Young, M. (2014). Effect of bentonite/potassium sorbate coatings on the quality of mangos in storage at ambient temperature. Journal of Food Engineering, 137, 16-22. http://dx.doi.org/10.1016/j.jfoodeng.2014.03.024

Low, P. S., \& Merida, J. R. (1996). The oxidative burst in plant defense: function and signal transduction. Physiologia Plantarum, 96, 533-42.

Ma, Z., Yang, L., Yan, H., Kennedy, J. F., \& Meng, X. (2013). Chitosan and oligochitosan enhance the resistance of peach fruit to brown rot. Carbohydrate Polymers, 94(1), 272-277. http://doi: 10.1016/j.carbpol.2013.01.012

Madani, B., Mohamed, M. T. M., Watkins, C. B., Kadir, J., Awang, Y., \& Shojaei, T. R. (2014). Preharvest calcium chloride sprays affect ripening of Eksotika II' papaya fruits during cold storage. Scientia Horticulturae, 171, 6-13.

http://dx.doi.org/10.1016/j.scienta.2014.03.032

Majid, I., Nayik, G. A., Dar, S. M., \& Nanda. V. (2016). Novel food packaging technologies: Innovations and future prospective. Journal of the Saudi Society of Agricultural Sciences, http://dx.doi.org/10.1016/j.jssas.2016.11.003

Mao, L. C., Wang, G. Z., Zhu, C. G., \& Pang, H. Q. (2007). Involvement of phospholipase D and lipoxygenase in response to chilling stress in postharvest cucumber fruits. Plant Science, 
172, 400-405. http://dx.doi.org/10.1016/j.plantsci.2006.10.002

Marangoni, A. G., Palma, T., \& Stanley, D. W. (1996). Membrane effects in postharvest physiology. Postharvest Biology and Technology, 7, 193-217.

http://dx.doi.org/10.1016/0925-5214(95)00042-9

Mari, M., Francesco, A. D., \& Bertolini, P. (2014). Control of fruit postharvest diseases: old issues and innovative approaches. Stewart Postharvest Review, 10, 1-4.

Meng, X. H., Li, B. Q., Liu, J., \& Tian, S. P. (2008). Physiological responses and quality attributes of table grape fruit to chitosan preharvest spray and postharvest coating during storage. Food Chemistry, 106, 501-508. http://dx.doi.org/10.1016/j.foodchem.2007.06.012

Nayik, G. A., \& Muzaffar, K. (2014). Developments in packaging of fresh fruits- shelf life perspective: A review. American Journal of Food Science and Nutrition Research, 1(5), 34-39.

Nayik, G. A., Majid, I., \& Kumar, V. (2015). Developments in Edible films and Coatings for the extension of Shelf Life of Fresh Fruits. American Journal of Nutrition and Food Science, $2(1), 16-2$.

Ojagh, S. M., Rezaei, M., Razavi, S. H., \& Hosseini, S. M. H. (2010). Effect of chitosan coatings enriched with cinnamon oil on the quality of refrigerated rainbow trout. Food Chemistry, 120, 193-198. http://dx.doi.org/10.1016/j.foodchem.2009.10.006

Palafox-Carlos, H., Yahia, E., Islas-Osuna, M. A., Gutierrez-Martinez, P., Robles-Sánchez, R. M., \& González-Aguilar, G. A. (2012). Effect of ripeness stage of mango fruit (Mangifera indica L., cv. Ataulfo) on physiological parameters and antioxidant activity. Scientia Horticulturae, 135, 7-13. http://dx.doi.org/10.1016/j.scienta.2011.11.027

Razzaq, K., Khan, A. S., Malik, A. U., Shahid, M., \& Ullah, S. (2014). Role of putrescine in regulating fruit softening and antioxidative enzyme systems in 'Samar Bahisht Chaunsa' mango. Postharvest Biology and Technology, 96, 23-32.

http://dx.doi.org/10.1016/j.postharvbio.2014.05.003

Romanazzi, G., Feliziani, E., Baños, S. B., \& Sivakumar, D. (2017). Shelf life extension of fresh fruit and vegetables by chitosan treatment. Critical Reviews in Food Science and Nutrition, 57(3), 579-601. http:// dx.doi:10.1080/10408398.2014.900474.

Saltveit, M. E. (2002). The rate of ion leakage from chilling-sensitive tissue does not immediately increase upon exposure to chilling temperatures. Postharvest Biology and Technology, 26, 295-304.

Shi, S., Wang, W., Liu, L., Wu, S., Wei, Y., \& Li, W. (2013). Effect of chitosan/nano-silica coating on the physicochemical characteristics of longan fruit under ambient temperature. Journal of Food Engineering, 118(1), 125-131.

http://dx.doi.org/10.1016/j.jfoodeng.2013.03.029

Siddique, H. R., \& Saleem, M. (2011). Beneficial health effects of lupeol triterpene: a review 
of preclinical studies. Life Science, 88, 285-293.

Singh, Z., \& Singh, S. P. (2012). Mango. In D. Rees, \& J. Orchard (Eds.), Crop Post-harvest: Science and Technology Volume 3 Perishables, 108-142. UK: Blackwell Publishing.

Tian, S., Qin, G., \& Li, B. (2013). Reactive oxygen species involved in regulating fruit senescence and fungal pathogenicity. Plant Molecular Biology, 82, 593-602. http://dx.doi: 10.1007/s11103-013-0035-2

Toivonen, P. M. A. (2003). Effects of storage conditions and postharvest procedures on oxidative stress in fruits and vegetables. In D. M. Hodges (Ed.), Postharvest oxidative stress in horticultural crops, 69-90. New York, Food Products Press.

Wang, S. Y., \& Gao, H. (2013). Effect of chitosan-based edible coating on antioxidants, antioxidant enzyme system, and postharvest fruit quality of strawberries (Fragaria $\mathrm{x}$ aranassa duch.). LWT-Food Science and Technology, 52(2), 71-79.

http://dx.doi.org/10.1016/j.lwt.2012.05.003

Wongmetha, O., \& Ke, L. S. (2012). The quality maintenance and extending storage life of mango fruit after postharvest treatments. World Academy of Science, Engineering and Technology, 69, 936-941.

Xing, Y., Li, X., Xu, Q., Yun, J., Lu, Y., \& Tang, Y. (2011). Effects of chitosan coating enriched with cinnamon oil on qualitative properties of sweet pepper (Capsicum annuum L.). Food Chemistry, 124, 1443-1450. http://dx.doi.org/10.1016/j.foodchem.2010.07.105

Yahia, E. M. (2010). The contribution of fruits and vegetables consumption to human health. In L. A. de la Rosa, E. Alvarez-Parilla, \& G. Gonzalez-Aguilar (Eds.), Fruit and vegetable phytochemicals: Chemistry, nutritional and stability, 3-52.Wiley-Blackwell, Iowa.

Yang, G., Yue, J., Gong, X., Qian, B., Wang, H., Deng, Y., \& Zhao, Y. (2014). Blueberry leaf extracts incorporated chitosan coatings for preserving postharvest quality of fresh blueberries.

Postharvest Biology and Technology, 92, 46-53.

http://dx.doi.org/10.1016/j.postharvbio.2014.01.018

Yang, H., Wu, F., \& Cheng, J. (2011). Reduced chilling injury in cucumber by nitric oxide and the antioxidant response. Food Chemistry, 127(3), 1237-1242.

http://dx.doi.org/10.1016/j.foodchem.2011.02.011

Zakrzewska, A., Boorsma, A., Brul, S., Hellingwerf, K. J., \& Klis, F. M. (2005). Transcriptional response of Saccharomyces to the plasma membrane-perturbing compound chitosan. Eukaryot Cell, 4, 703-715. http://dx.doi:10.1128/EC.4.4.703-715.2005

Zhang, J., Bruton, B. D., \& Biles, C. L. (1997). Polygalacturonase isozymes produced by Phomopsis cucurbitae in relation to postharvest decay of cantaloupe fruit. Phytopathology, 87, 1020-1025. http://dx.doi:10.1094/PHYTO.1997.87.10.1020

Zhou, H. W., Dong, L., Ben-Arie, R., \& Lurie, S. (2000). Pectin esterase, polygalacturonase and gel formation in peach pectin fractions. Phytochemistry, 55, 191-195. 


\section{Macrothink}

Journal of Agricultural Studies

ISSN 2166-0379 2017, Vol. 5, No. 2

Zhou, R., Li, Y., Yan, L., \& Xie, J. (2011). Effect of edible coatings on enzymes, cell-membrane integrity, and cell-wall constituents in relation to brittleness and firmness of huanghua pears (Pyrus pyrifolia Nakai, cv. Huanghua) during storage. Food Chemistry, 124, 569-575. http://dx.doi.org/10.1016/j.foodchem.2010.06.075

Zieslin, N., \& Ben-Zaken, R. (1993). Peroxidase activity and presence of phenolic substances in peduncles of rose flowers. Plant Physiology and Biochemistry, 31, 333-339.

\section{Copyright Disclaimer}

Copyright for this article is retained by the author(s), with first publication rights granted to the journal.

This is an open-access article distributed under the terms and conditions of the Creative Commons Attribution license (http://creativecommons.org/licenses/by/4.0/). 